\title{
MATERIAL REMOVAL RATE DURING CHROMIUM ABRASIVES MIXED EDM OF EN19 STEEL
}

\author{
Jaisukhpal Singh ${ }^{1}$, Harvinder Lal $^{2}$ and Paramjit Singh ${ }^{3}$
}

\begin{abstract}
EN19 steel is an valuable material for mechanical applications in industrial use. This steel have good properties to use in industrial applications. In this study, chromium $(\mathrm{Cr})$ abrasives mixed kerosene fluid is used to drill blind holes in EN19 steel work piece. Factors like concentration of chromium abrasives in kerosene oil $\left(\mathrm{C}_{\mathrm{a}}\right)$, copper tool electrode polarity $\left(\mathrm{E}_{\mathrm{p}}\right)$, discharge current $\left(\mathrm{I}_{\mathrm{d}}\right)$, pulse on time $\left(\mathrm{T}_{\mathrm{on}}\right)$, pulse off time $\left(\mathrm{T}_{\text {off }}\right)$, and discharge voltage $\left(\mathrm{V}_{\mathrm{d}}\right)$ are varied as per $\mathrm{L}_{18}$ orthogonal array of Taguchi method to measure the material removal rate (MRR) of the EN19 steel. Appropriate addition of abrasives in kerosene oil is found to be fruitful for improvement in MRR of EN19 steel.

Keywords - EN19, EDM, material removal rate.
\end{abstract}

\section{INTRODUCTION}

EDM, a non-traditional machining technique is very common to produce intricate shapes on dies. Possibility of EDM is due to the action of sparks of short duration and high discharge current intensity between two mating parts. The technique is able to cut precisely with good surface finish by modifying the process input [1]. EDM involves the conversion of electrical energy into thermal energy in inter-electrode space in presence of dielectric fluid. Chow et al., (2008) studied the mixture of SiC abrasives in pure water as dielectric during EDM process. It was proved that $\mathrm{SiC}$ abrasives enhances the fluid conductivity and extrudes worn debris easily and enlarges gap distanceReddy et al. (2012) used Taguchi Technique to vary pulse-on, pulse-off, Bed speed and Current during WEDM of EN19 steel. Regression analysis is carried-out study the trend of the MRR of EN19 and SS420 steels. It was proved that the EN 19 is more suitable for high MRR and AISI 420 for higher surface finish. Vikas et al. (2014) worked on EDM of EN19 steel through variation of factors like pulse on time, pulse off time, discharge current and voltage. Impact of the carbon percentage over the MRR was also investigated. Discharge current had a proved to be the larger impact factor as compare to other factors on MRR of EN19. Murahari et al (2014) noted the effect of additives added in the dielectric fluid on EDM of Ti-6AL-4V.

A series of investigations are available in EDM of steels and other non ferrous materials. A few research works are available in the direction of mixing conductive metal abrasives in kerosene oil during EDM of EN19 steel. Therefore, this study aimed to analyze the effect of chromium $(\mathrm{Cr})$ abrasives mixed in kerosene oil to use as dielectric during EDM of EN19 steel.

\footnotetext{
${ }^{1}$ Department of Mechanical Engineering, Ramgarhia Institute of Engineering \& Technology, Phagwara, Punjab, India

${ }^{2}$ Department of Mechanical Engineering, Ramgarhia Institute of Engineering \& Technology, Phagwara, Punjab, India

${ }^{3}$ Department of Mechanical Engineering, Amritsar College of Engineering \& Technology, Amritsar, Punjab, India
} 


\section{EXPERIMENTATION}

A. Equipment and materials

18 experiments were performed on OSCARMAX S645 EDM machine (Figure 1). Attached dielectric system of machine was taken for experiments without suspending $\mathrm{Cr}$ abrasives. Otherwise, one 10 litre capacity box was manufactured in welding workshop to perform $\mathrm{Cr}$ mixed experiments. All experiments in which $10 \mathrm{~g} / \mathrm{l}$ and $5 \mathrm{~g} / \mathrm{l} \mathrm{Cr}$ abrasives mixed kerosene dielectric fluid were used are performed in this box. To homogenize mix the $\mathrm{Cr}$ abrasives in dielectric, small pump with $0.40 \mathrm{~m}$ long nozzle was used in metal box.

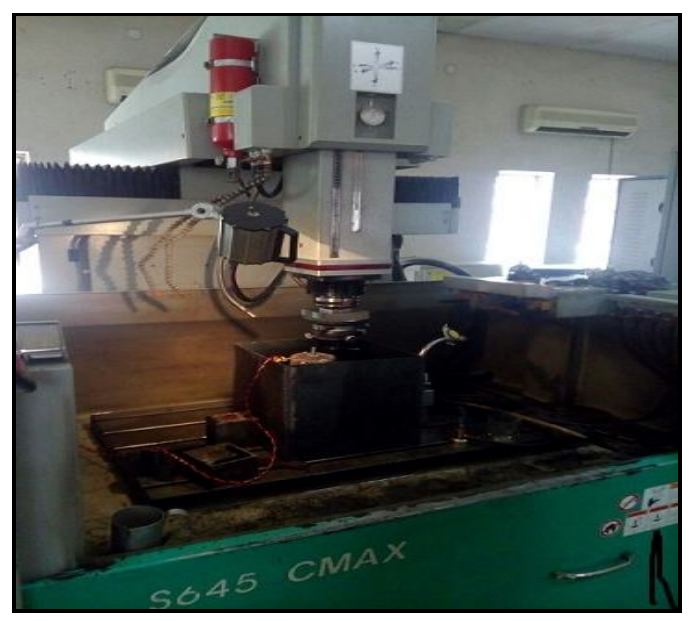

Figure 1. OSCARMAX S645 EDM Machine

A cylindrical solid electrolytic copper $\operatorname{rod}(\Phi=9 \mathrm{~mm})$ with specific properties shown in Table 1 was taken as tool electrode. $100 \mu \mathrm{m}$ grain size Cr. abrasives are suspended in dielectric. EN19 steel with specific properties listed in Table 2 was taken as work material. The experimental specimen of EN19 was cut into rectangular plate.

Table 1. Various properties of copper

\begin{tabular}{|c|c|c|c|c|c|c|}
\hline Property & $\begin{array}{l}\text { Specific } \\
\text { heat } \\
\text { capacity }\end{array}$ & $\begin{array}{l}\text { Melting } \\
\text { point }\end{array}$ & $\begin{array}{l}\text { Co-eff. Of thermal } \\
\text { exp. }\end{array}$ & Density & $\begin{array}{l}\text { Electrical } \\
\text { Resistivity }\end{array}$ & $\begin{array}{l}\text { Thermal } \\
\text { conductivity }\end{array}$ \\
\hline Value & $\begin{array}{l}0.385 \quad \mathrm{~J} / \mathrm{g}- \\
\mathrm{K}\end{array}$ & $1360 \mathrm{~K}$ & $0.000017 / /^{\circ} \mathrm{C}$ & $\begin{array}{l}8.94 \\
\mathrm{~g} / \mathrm{cm}^{3}\end{array}$ & 17.1 n. $\Omega . m$ & $226 \mathrm{~W} / \mathrm{m} . \mathrm{K}$ \\
\hline
\end{tabular}

Table 2. Chemical composition of EN19 (wt \%)

\begin{tabular}{|l|l|l|l|l|l|l|l|}
\hline Element & Mo & Cr & P & S & Si & Mn & C \\
\hline Wt (\%) & $0.20-$ & $\mathbf{0 . 9 0 - 1 . 4 0}$ & $\mathbf{0 . 0 4}$ & $\mathbf{0 . 0 4}$ & $\mathbf{0 . 1 0 -}$ & $\mathbf{0 . 5 0 -}$ & $\mathbf{0 . 3 5 -}$ \\
& 0.40 & & & & 0.35 & 0.80 & 0.45 \\
\hline
\end{tabular}

\section{EXPERIMENTATION}

\section{A. Input Factors and response variable selected}


Chromium abrasives suspended in dielectric fluid plays a crucial role in evaluating the EDM characteristics of the EN19 steel. Input factors taken in the study are electrode polarity $\left(E_{p}\right)$, discharge current $\left(I_{d}\right)$, pulse on time $\left(T_{\text {on }}\right)$, pulse off time $\left(T_{\text {off }}\right)$, discharge voltage $\left(V_{d}\right)$, and concentration of abrasives $\left(\mathrm{C}_{\mathrm{a}}\right)$. Five factors varied at three levels and one factor varied at two levels as per the values given in Table 3. Taguchi recommended $\left(\mathrm{L}_{18}\right)$ is used to design the experimental runs. Table 4 shows the coded values of factors, actual values of factors, MRR, S/N ratios and means obtained in these 18 experiments. MRR is expressed as material eroded away from the EN19 steel per unit time. The EN19 steel weight was measured using electronic weight balance of $0.001 \mathrm{mg}$ resolution. These values are used in Eq. (1) to calculate MRR values.

Table 3. Values of input machining factors at all levels

\begin{tabular}{|c|c|c|c|c|}
\hline \multirow[t]{2}{*}{ Designation } & \multirow[t]{2}{*}{ Machining factor } & \multicolumn{3}{|c|}{$\begin{array}{l}\text { Levels and corresponding values of machining } \\
\text { factor }\end{array}$} \\
\hline & & Level 1 & Level 2 & Level 3 \\
\hline $\mathbf{E}_{\mathbf{p}}$ & Electrode Polarity & Positive & Negative & --- \\
\hline $\mathbf{I}_{\mathrm{d}}$ & Discharge Current & $4 \mathrm{~A}$ & $\mathbf{8 A}$ & 12A \\
\hline $\mathbf{T}_{\text {on }}$ & Pulse on time & $90 \mu s$ & $150 \mu s$ & $200 \mu s$ \\
\hline$T_{\text {off }}$ & Pulse off time & $30 \mu s$ & $45 \mu s$ & $60 \mu s$ \\
\hline $\mathbf{V}_{\mathrm{d}}$ & Discharge Voltage & 30 volt & 40 volt & 50 volt \\
\hline $\mathbf{C}_{\mathbf{a}}$ & $\begin{array}{l}\text { Concentration } \\
\text { abrasives }\end{array}$ & $0 \mathrm{~g} / \mathrm{l}$ & $5 \mathrm{~g} / 1$ & $10 \mathrm{~g} / \mathrm{l}$ \\
\hline
\end{tabular}

Eq. (1) is taken to calculate MRR

$$
\operatorname{MRR}=\frac{\text { Work piece material weight loss }(\mathrm{g})}{\text { Operation time }(\min )}
$$

EN19 plate is cut from the raw piece as per desired dimensions. Copper rod is machined and cut to form electrode. Taking $\mathrm{L}_{18} \mathrm{OA}$ using Taguchi method, $\mathrm{Cr}$ abrasives were selected with $100 \mu \mathrm{m}$ grain size and mixed in kerosene oil for the experimental work. After selecting all the six machining factors, electrode, EN19 work-piece, $\mathrm{Cr}$ abrasives, kerosene oil and machine tool next step was to conduct the runs. Starting from the measurement of initial weight of EN19 plate, with the help of weight balance, work-piece and electrode were fixed in the fixture. As per data in table 3 and table 4 , various factors like $E_{p}, I_{d}, T_{o n}, T_{\text {off }}, V_{d}$ and $C_{a}$ were applied and varied on the EDM machine tool with the help of a PLC system. All the experiments were conducted accordingly.

\begin{tabular}{|c|c|c|c|c|c|c|c|c|c|c|c|c|c|c|c|}
\hline \multirow{2}{*}{$\begin{array}{l}\text { Exp } \\
\text { No. }\end{array}$} & \multicolumn{6}{|c|}{ Coded factors } & \multicolumn{6}{|c|}{ Actual factors } & \multirow{2}{*}{$\begin{array}{l}\text { MRR } \\
\text { (g/min) }\end{array}$} & \multirow{2}{*}{$\begin{array}{l}\text { S/N } \\
\text { Ratios }\end{array}$} & \multirow{2}{*}{$\begin{array}{l}\text { Means } \\
\text { Value }\end{array}$} \\
\hline & $\mathrm{E}_{\mathrm{p}}$ & $\mathrm{I}_{\mathrm{d}}$ & $\begin{array}{l}\mathrm{T}_{\mathrm{o}} \\
\mathrm{n}\end{array}$ & $\begin{array}{l}T_{\text {of }} \\
f\end{array}$ & $\mathrm{~V}_{\mathrm{d}}$ & $\mathrm{C}_{\mathrm{a}}$ & $\mathrm{E}_{\mathrm{p}}$ & $\mathrm{I}_{\mathrm{d}}$ & $\mathrm{T}_{\mathrm{on}}$ & $\begin{array}{l}T_{\text {of }} \\
f\end{array}$ & $\mathrm{~V}_{\mathrm{d}}$ & $\mathrm{C}_{\mathrm{a}}$ & & & \\
\hline 1 & 1 & 1 & 1 & 1 & 1 & 1 & $+\mathrm{ve}$ & 4 & 90 & 30 & 30 & 0 & $\begin{array}{l}0.02000 \\
0\end{array}$ & $\begin{array}{l}- \\
33.9794\end{array}$ & 0.02 \\
\hline 2 & 1 & 1 & 2 & 2 & 2 & 2 & $+\mathrm{ve}$ & 4 & 150 & 45 & 40 & 5 & $\begin{array}{l}0.01434 \\
5\end{array}$ & $\begin{array}{l}- \\
36.8659\end{array}$ & $\begin{array}{l}0.01434 \\
5\end{array}$ \\
\hline 3 & 1 & 1 & 3 & 3 & 3 & 3 & $+\mathrm{ve}$ & 4 & 200 & 60 & 50 & 10 & $\begin{array}{l}0.00895 \\
0\end{array}$ & $\begin{array}{l}- \\
40.9637\end{array}$ & 0.00895 \\
\hline 4 & 1 & 2 & 1 & 1 & 2 & 2 & $+v e$ & 8 & 90 & 30 & 40 & 5 & $\begin{array}{l}0.11208 \\
8\end{array}$ & $\begin{array}{l}- \\
19.0088\end{array}$ & $\begin{array}{l}0.11208 \\
8\end{array}$ \\
\hline
\end{tabular}

Table 4. Used $\mathrm{L}_{18} \mathrm{OA}$ with MRR, S/N and Means values 


\begin{tabular}{|l|l|l|l|l|l|l|l|l|l|l|l|l|l|l|l|}
\hline 5 & 1 & 2 & 2 & 2 & 3 & 3 & $+\mathrm{ve}$ & 8 & 150 & 45 & 50 & 10 & $\begin{array}{l}0.08345 \\
9\end{array}$ & $\begin{array}{l}-21.5706 \\
2\end{array}$ \\
\hline 6 & 1 & 2 & 3 & 3 & 1 & 1 & $+\mathrm{ve}$ & 8 & 200 & 60 & 30 & 0 & $\begin{array}{l}0.08470 \\
6\end{array}$ & $\begin{array}{l}- \\
21.4417\end{array}$ & $\begin{array}{l}0.08470 \\
6\end{array}$ \\
\hline 7 & 1 & 3 & 1 & 2 & 1 & 3 & $+\mathrm{ve}$ & 12 & 90 & 45 & 30 & 10 & $\begin{array}{l}0.22784 \\
8\end{array}$ & $\begin{array}{l}- \\
12.8471\end{array}$ & $\begin{array}{l}0.22784 \\
8\end{array}$ \\
\hline 8 & 1 & 3 & 2 & 3 & 2 & 1 & $+\mathrm{ve}$ & 12 & 150 & 60 & 40 & 0 & $\begin{array}{l}0.17073 \\
2\end{array}$ & $\begin{array}{l}- \\
15.3537\end{array}$ & $\begin{array}{l}0.17073 \\
2\end{array}$ \\
\hline 9 & 1 & 3 & 3 & 1 & 3 & 2 & $+\mathrm{ve}$ & 12 & 200 & 30 & 50 & 5 & $\begin{array}{l}0.19800 \\
0\end{array}$ & - \\
14.0667 & 0.198 \\
\hline 10 & 2 & 1 & 1 & 3 & 3 & 2 & $-\mathrm{ve}$ & 4 & 90 & 60 & 50 & 5 & $\begin{array}{l}0.00239 \\
7\end{array}$ & $\begin{array}{l}- \\
52.4084\end{array}$ & $\begin{array}{l}0.00239 \\
7\end{array}$ \\
\hline 11 & 2 & 1 & 2 & 1 & 1 & 3 & $-\mathrm{ve}$ & 4 & 150 & 30 & 30 & 10 & $\begin{array}{l}0.00222 \\
9\end{array}$ & $\begin{array}{l}- \\
53.0395\end{array}$ & $\begin{array}{l}0.00222 \\
9\end{array}$ \\
\hline 12 & 2 & 1 & 3 & 2 & 2 & 1 & $-\mathrm{ve}$ & 4 & 200 & 45 & 40 & 0 & $\begin{array}{l}0.00146 \\
7\end{array}$ & $\begin{array}{l}- \\
56.6686\end{array}$ & $\begin{array}{l}0.00146 \\
7\end{array}$ \\
\hline 13 & 2 & 2 & 1 & 2 & 3 & 1 & $-\mathrm{ve}$ & 8 & 90 & 45 & 50 & 0 & $\begin{array}{l}0.00568 \\
6\end{array}$ & $\begin{array}{l}- \\
44.9035\end{array}$ & $\begin{array}{l}0.00568 \\
6\end{array}$ \\
\hline 14 & 2 & 2 & 2 & 3 & 1 & 2 & $-\mathrm{ve}$ & 8 & 150 & 60 & 30 & 5 & $\begin{array}{l}0.00645 \\
9\end{array}$ & $\begin{array}{l}- \\
43.7968\end{array}$ & $\begin{array}{l}0.00645 \\
9\end{array}$ \\
\hline 15 & 2 & 2 & 3 & 1 & 2 & 3 & $-\mathrm{ve}$ & 8 & 200 & 30 & 40 & 10 & $\begin{array}{l}0.00628 \\
2\end{array}$ & - \\
44.0387 & $\begin{array}{l}0.00628 \\
2\end{array}$ \\
\hline 16 & 2 & 3 & 1 & 3 & 2 & 3 & $-\mathrm{ve}$ & 12 & 90 & 60 & 40 & 10 & $\begin{array}{l}0.00297 \\
4\end{array}$ & $\begin{array}{l}-50.532 \\
0.00297 \\
4\end{array}$ \\
\hline 17 & 2 & 3 & 2 & 1 & 3 & 1 & $-\mathrm{ve}$ & 12 & 150 & 30 & 50 & 0 & $\begin{array}{l}0.00564 \\
3\end{array}$ & $\begin{array}{l}- \\
44.9691\end{array}$ & $\begin{array}{l}0.00564 \\
3\end{array}$ \\
\hline 18 & 2 & 3 & 3 & 2 & 1 & 2 & $-\mathrm{ve}$ & 12 & 200 & 45 & 30 & 5 & $\begin{array}{l}0.00907 \\
4\end{array}$ & $\begin{array}{l}- \\
40.8443\end{array}$ & $\begin{array}{l}0.00907 \\
4\end{array}$ \\
\hline
\end{tabular}

Time of cut (TOC) was taken 40 minutes for each run. After fixed TOC, machine finished operation and gets stop automatically. Both tool and EN19 steel were removed from the machine fixture and cleaned. Final weights of EN19 plate measured with the help of weight balance. Abrasives mixed EDM experiments were performed in steel tank to prevent any clogging due to chromium abrasives in integrated flushing system of machine tool. For all runs, initial and final weight of EN19 plate are measured and used in Eq. (1) to calculate MRR.

\section{RESULTS AND DISCUSSION}

\section{A. The effect of $\mathrm{Cr}$ on discharge mechanism:}

Cr presence reduces the insulating strength of kerosene and increase the spark gap between EN19 steel and copper rod. This is more efficient process with improved machining efficiency. The spark gap area is filled by $\mathrm{Cr}$ abrasive particles and increase the gap distance in EN19 plate and counter face electrode. These particles form clusters in sparking area. They interlink among each other due to different shapes of tiny particles and forms the chains at minute distances apart. Due to this uniform distribution of discharge occurs which cause uniform wear away on EN19 steel. This results in improved MRR. In the current study work, Taguchi method is used to analyze the results of MRR for larger the better criteria. Table 5 describes the ANOVA and F-test data for $\mathrm{S} / \mathrm{N}$ ratios for MRR.

Table 5. ANOVA for S/N ratio and F-test data for MRR

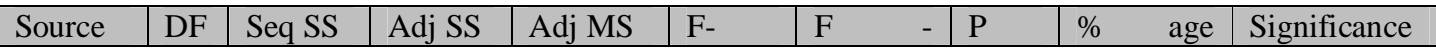




\begin{tabular}{|l|l|l|l|l|l|l|l|l|l|}
\hline & & & & & value & critical* & & contr. & \\
\hline $\mathrm{E}_{\mathrm{p}}$ & 1 & 2570.53 & 2570.53 & 2570.53 & 85.28 & 5.99 & 0.000 & 69.70 & Significant \\
\hline $\mathrm{I}_{\mathrm{d}}$ & 2 & 867.35 & 867.35 & 433.68 & 14.39 & 5.14 & 0.005 & 23.52 & Significant \\
\hline $\mathrm{T}_{\mathrm{on}}$ & 2 & 1.58 & 1.58 & 0.79 & 0.03 & 5.14 & 0.974 & 0.04 & $\begin{array}{l}\text { Non } \\
\text { significant }\end{array}$ \\
\hline $\mathrm{T}_{\text {off }}$ & 2 & 20.82 & 20.82 & 10.41 & 0.35 & 5.14 & 0.721 & 0.57 & $\begin{array}{l}\text { Non } \\
\text { significant }\end{array}$ \\
\hline $\mathrm{V}_{\mathrm{d}}$ & 2 & 25.17 & 25.17 & 12.58 & 0.42 & 5.14 & 0.676 & 0.68 & $\begin{array}{l}\text { Non } \\
\text { significant }\end{array}$ \\
\hline $\mathrm{C}_{\mathrm{a}}$ & 2 & 21.94 & 21.94 & 10.97 & 0.36 & 5.14 & 0.709 & 0.60 & $\begin{array}{l}\text { Non } \\
\text { significant }\end{array}$ \\
\hline $\begin{array}{l}\text { Residual } \\
\text { error }\end{array}$ & 6 & 180.86 & 180.86 & 30.14 & & & & & \\
\hline Total & 17 & 3688.24 & & & & & & & \\
\hline
\end{tabular}

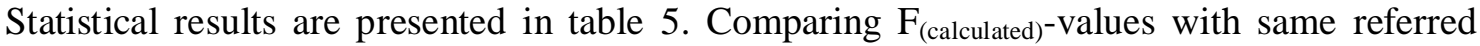
from "table for statisticians" it is witnessed that $E_{p}$ and $I_{d}$ has the significant effect. F-value of $E_{p}$ is larger than factors, which proves that $E_{p}$ has highest contribution $(69.70 \%)$ followed by $I_{d}(23.52 \%)$ towards MRR. Significant effect of $E_{p}$ and $I_{d}$ is also observed from their

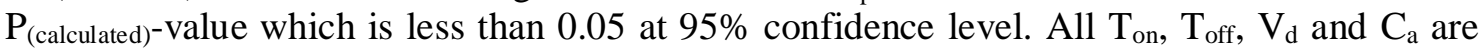
affecting MRR for contribution of $0.04 \%, 0.57 \%, 0.68 \%$ and $0.6 \%$ respectively. Calculated F-value of $T_{o n}, T_{\text {off }}, V_{d}$ and $C_{a}$ is less than their table of statisticians' F-value; which shows that their affect is non-significant. Similarly, their P-value (more than 0.05) further proves that their affect is non-significant. Above results are drawn at 95\% confidence level $(\alpha=$ $0.05)$.

Table 6. Response table for $\mathrm{S} / \mathrm{N}$ ratio for MRR

\begin{tabular}{|c|c|c|c|c|c|c|c|}
\hline Level & $\mathrm{E}_{\mathrm{p}}$ & $\mathrm{I}_{\mathrm{d}}$ & $\mathrm{T}_{\text {on }}$ & $\mathrm{T}_{\text {off }}$ & $\mathrm{V}_{\mathrm{d}}$ & $\mathrm{C}_{\mathrm{a}}$ & $\begin{array}{l}\text { Mean } \\
\left(\mathrm{E}_{\mathrm{p}}+\mathrm{I}_{\mathrm{d}}+\mathrm{T}_{\text {on }}+\mathrm{T}_{\text {off }}+\mathrm{V}_{\mathrm{d}}+\mathrm{C}_{\mathrm{a}}\right) / 6\end{array}$ \\
\hline 1 & $-\overline{24.01}$ & $-\overline{45.65}$ & $-\overline{35.61}$ & $-\overline{34.85}$ & $-\overline{34.32}$ & $-\overline{36.22}$ & -35.11 \\
\hline 2 & $-\overline{4}+91$ & $-\overline{32.46}$ & - & $-\overline{35.62}$ & $\begin{array}{l}- \\
37.08\end{array}$ & $-\overline{3}-5$ & -37.25 \\
\hline 3 & & $\begin{array}{l}- \\
29.77\end{array}$ & $\begin{array}{l} \\
36.34 \\
\end{array}$ & $\begin{array}{l} \\
37.42 \\
\end{array}$ & $\begin{array}{l}- \\
36.48\end{array}$ & $\begin{array}{l} \\
37.17\end{array}$ & -35.44 \\
\hline Delta & 23.90 & 15.89 & 0.72 & 2.57 & 2.75 & 2.67 & \\
\hline Rank & 1 & 2 & 6 & 5 & 3 & 4 & \\
\hline
\end{tabular}

$\mathrm{S} / \mathrm{N}$ ratios of each run are computed to their average for each factor and level. Each factor and concerned levels have extreme $\mathrm{S} / \mathrm{N}$ ratios (biggest and smallest). These extreme $\mathrm{S} / \mathrm{N}$ values are used to compute delta statistic in response table 6. Delta statistic computes the relative extent of factor affect. Highest 'delta' statistic of $\mathrm{E}_{\mathrm{p}}$ is ranking it the most prominent factor and lowest 'delta' for $\mathrm{T}_{\text {on }}$ is ranking it the least affecting factor. Figure 2 presents main effect plot for $\mathrm{S} / \mathrm{N}$ ratios of MRR. 


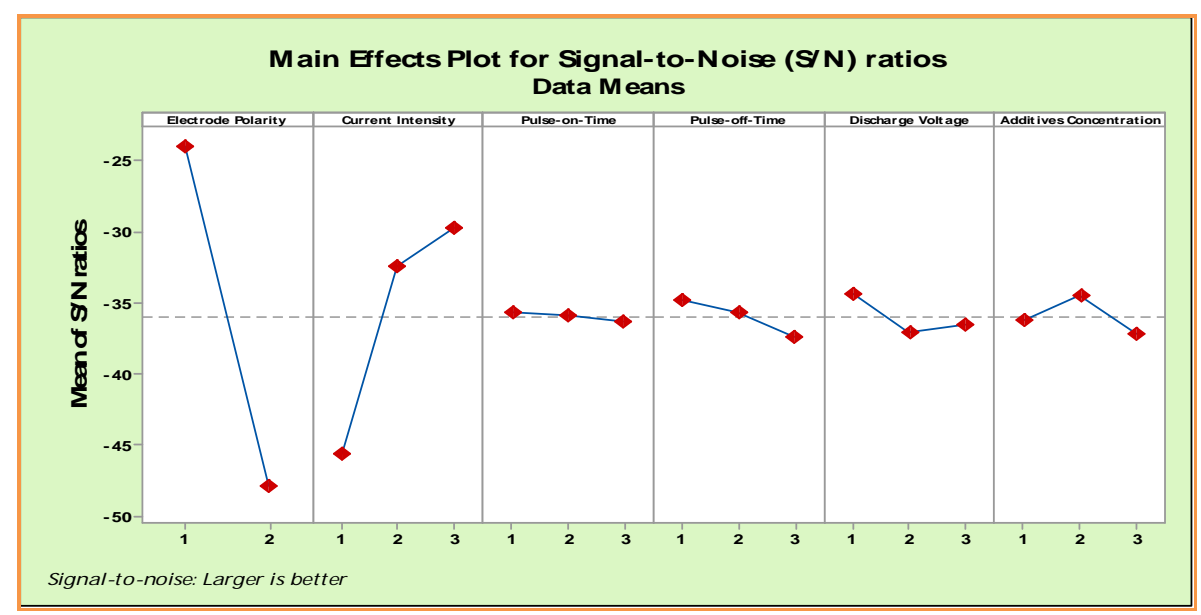

Figure 2. Main effects plot for $\mathrm{S} / \mathrm{N}$ ratios for MRR

More is the MRR at $1^{\text {st }}$ level of $E_{p}$ compared to its $2^{\text {nd }}$ level. Powerful sparking maintains high temperature at $3^{\text {rd }}$ level $\mathrm{I}_{\mathrm{d}}$, results in more eroding EN19 plate and hence more MRR. Increase in $\mathrm{T}_{\text {on }}$ from $1^{\text {st }}$ to $3^{\text {rd }}$ level swell the plasma channel in the inter-electrode space results diminishes of thermal energy density in the spark and hence removing less EN19 material. Increment in $\mathrm{T}_{\text {off }}$ from level $1^{\text {st }}$ to $3^{\text {rd }}$ reduces MRR because more the time spark

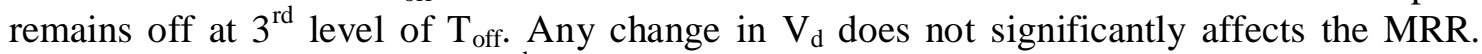
With the suspension of $\mathrm{Cr}$ (at $2^{\text {nd }}$ level) abrasives into the kerosene oil during EDM of EN19, MRR starts its increasing trend. Presence of optimized $\mathrm{Cr}$ abrasives in kerosene oil at level 2 is responsible for increased MRR. Due to which, quickly discharging occurs and removes more EN19 steel.

\section{CONCLUSIONS}

On the basis of experimental study, following conclusions are drawn:

1. Mixed $\mathrm{Cr}$ abrasives in kerosene oil upto a certain value as dielectric improves MRR of EDM of EN19 steel.

2. At high peak currents $\left(\mathrm{I}_{\mathrm{d}}\right)$, powerful sparking occurs, resulting the raise in temperature, causing more melting and wear away of EN19 plate. Result is improved MRR.

3. Optimum addition of chromium abrasives in kerosene oil is helpful to improve MRR.

\section{REFERENCES}

[1] W.S. Zhao, "The applications of research on powder mixed EDM in rough machining", 129 (1-3), pp. 3033, 2002.

[2] H. Chow, L. Yang, C.T. Lin, and Y-F. Chen, "The use of SiC powder in water as dielectric for micro-slit EDM machining”, Journal of Material Processing Technology, 195, pp. 160-170, 2008.

[3] C.B. Reddy, V.D. Reddy and C.E. Reddy, "Experimental investigations on MRR and surface roughness of EN 19 \& SS 420 steels in wire EDM using Taguchi method”, International Journal of Engineering Science and Technology, Vol. 4, 2012.

[4] Vikas, Shashikant, A.K. Roy and K. Kumar, "Effect and Optimization of Machine Process Parameters on MRR for EN19 \& EN41 Materials Using Taguchi”, Procedia Technology, 14, 2014, pp. 204-210.

[5] Murahari Kolli and Adepu Kumar, "Effect of additives added in dielectric fluid on EDM of titanium alloy", In Proceedings of International Conference on Advance Research and Innovations in Mechanical, Material Science, Industrial Engineering and Management, January 6-7, 2014, India. 